\title{
Role of Insulin-Like Growth Factor Binding Protein 2 in Lung Adenocarcinoma
}

\section{IGF-Independent Antiapoptotic Effect Via Caspase-3}

\author{
Toshiro Migita, ${ }^{*}$ Tadahito Narita, ${ }^{* \dagger}$ Reimi Asaka, ${ }^{*}$ \\ Erika Miyagi, ${ }^{*}$ Hiroko Nagano, ${ }^{*}$ Kimie Nomura, ${ }^{*}$ \\ Masaaki Matsuura, ${ }^{\ddagger \S}$ Yukitoshi Satoh, ${ }^{\pi}$ \\ Sakae Okumura, " Ken Nakagawa, ${ }^{\text {"ा }}$ \\ Hiroyuki Seimiya, and Yuichi Ishikawa* \\ From the Divisions of Pathology, ${ }^{*}$ and Cancer Genomics, ${ }^{*}$ The \\ Cancer Institute, Tokyo; Zenyaku Kogyo Co., Ltd., ${ }^{\dagger}$ Tokyo; the \\ Bioinformatics Group, ${ }^{\S}$ Genome Center, Tokyo; the Department of \\ Thoracic Surgical Oncology, "I and the Division of Molecular \\ Biotherapy," Cancer Chemotherapy Center, The Cancer Institute \\ Hospital, Japanese Foundation for Cancer Research, Tokyo, Japan
}

Insulin-like growth factor (IGF) signaling plays a pivotal role in cell proliferation and mitogenesis. Secreted IGFbinding proteins (IGFBPs) are important modulators of IGF bioavailability; however, their intracellular functions remain elusive. We sought to assess the antiapoptotic properties of intracellular IGFBP-2 in lung adenocarcinomas. IGFBP-2 overexpression resulted in a decrease in procaspase- 3 expression; however, it did not influence the phosphorylation status of either IGF receptor or its downstream targets, including Akt and extracellular signal-regulated kinase. Apoptosis induced by camptothecin was significantly inhibited by IGFBP-2 overexpression in NCI-H522 cells. Conversely, selective knockdown of IGFBP-2 using small-interfering RNA resulted in an increase in procaspase- 3 expression and sensitization to camptothecin-induced apoptosis in NCIH522 cells. LY294002, an inhibitor of phosphatidylinositol 3-kinase, caused a decrease in IGFBP-2 levels and enhanced apoptosis in combination with camptothecin. Immunohistochemistry demonstrated that intracellular IGFBP-2 was highly expressed in lung adenocarcinomas compared with normal epithelium. Intracellular IGFBP-2 and procaspase-3 were expressed in a mutually exclusive manner. These findings suggest that intracellular IGFBP-2 regulates caspase-3 expression and contributes to the inhibitory effect on apoptosis independent of IGF. IGFBP-2, therefore, may offer a novel therapeutic target and serve as an antiapoptotic biomarker for lung adenocarcinoma. (Am J Pathol 2010, 176:1756-1766; DOI: 10.2353/ajpath.2010.090500)

Insulin-like growth factor-I and -II (IGF-I and -II) are important regulators of cellular metabolism, growth, and survival. When IGFs bind to their receptors, the type I and type II IGF receptors (IGF-IR or IGF-IIR), they activate the downstream signaling cascades via the phosphorylation of tyrosine kinase. Activated IGF-1R transmits signals to the major distinct pathways mitogen-activated protein kinase and phosphatidyl inositol 3-kinase (PI3K), signaling pathways that are highly implicated in the development and progression of neoplasia. IGF's bioavailability is regulated by six high affinity IGF binding proteins (IGFBPS). Secreted IGFBPs by cancer cells interfere primarily with IGF-I or -II through the formation of IGFIGFBPs complex, which in turn exert an inhibitory effect on IGF-mediated biological functions.

IGF-independent functions of extracellular IGFBPs have long been discussed. Secreted and membraneassociated IGFBP-2 directly binds to proteoglycans and integrins, ${ }^{1-5}$ demonstrating IGFBP-2 as a negative or positive regulator of cell adhesion, migration, and invasion in an IGF-independent manner. In the same way, IGFBP-2 positively or negatively regulates cell growth

Supported by Grants-in-Aid for Scientific Research on Priority Areas from the Ministry of Education, Culture, Sports, Science, and Technology; Grants-in-Aid for Scientific Research from the Japan Society for the Promotion of Science; and by grants from the Ministry of Health, Labor, and Welfare, the National Institute of Biomedical Innovation, the Smoking Research Foundation, and the Vehicle Racing Commemorative Foundation.

Accepted for publication December 8, 2009

Current address of T.M.: Division of Molecular Biotherapy, Cancer Chemotherapy Center, Japanese Foundation for Cancer Research, Tokyo, Japan.

Address reprint requests to Toshiro Migita, M.D., Ph.D., Division of Molecular Biotherapy, Cancer Chemotherapy Center, Japanese Foundation for Cancer Research, 3-8-31, Ariake, Koto-ku, Tokyo 135-8550, Japan. E-mail: toshiro.migita@jfcr.or.jp. 
and survival in certain types of cancers in vitro. ${ }^{2,6-11}$ In in vivo studies, the growth of mice colorectal adenomas induced by chemical carcinogen was inhibited when they were crossed with IGFBP-2 transgenic mice ${ }^{12}$; however, in contrast, IGFBP-2 exerts oncogenic effects in brainspecific transgenic mice. ${ }^{13}$ Thus, increased IGFBP-2 confers advantage or disadvantage for tumor growth, depending on cell type and physiological conditions. ${ }^{2,14}$

Despite these two opposite effects of IGFBP-2 on biological behaviors of cancers, biochemistry and molecular pathology have demonstrated that IGFBP-2 is overexpressed in a wide variety of human malignancies, including glioma, ${ }^{15}$ prostate cancer, ${ }^{16}$ lung cancer, ${ }^{17-19}$ colorectal cancer, ${ }^{20}$ ovarian cancer, ${ }^{21}$ adrenocortical tumor, ${ }^{22}$ breast cancer, ${ }^{23}$ and leukemia. ${ }^{24}$ Importantly, IGFBP-2 is frequently overexpressed in advanced cancers and is suggested to be involved in the metastatic process. ${ }^{25}$ Several potential mechanisms of cancer progression mediated by secreted IGFBP-2 are discussed, ${ }^{14}$ but little study has been conducted to the analysis of intracellular-IGFBP-2 functions.

Our aim for this study is to examine the effect of intracellular IGFBP-2 on apoptosis in lung cancer cells and elucidate its molecular mechanism. We also examine the significance of intracellular IGFBP-2 and procaspase-3 in clinical samples and explore the therapeutic implications.

\section{Materials and Methods}

\section{Cell Culture and Clinical Samples}

The human lung adenocarcinoma cell lines A549, NClH460, NCl-H23, NCl-H522, HOP62, COR-L105, and PC14 were obtained from the American Type Culture Collection (Manassas, VA) and grown in RPMI 1640 media supplemented with $10 \%$ fetal bovine serum (both medium and serum were from Gibco-BRL, Tokyo, Japan) and 1\% penicillin/streptomycin in an atmosphere of $5 \% \mathrm{CO}_{2}$ at $37^{\circ} \mathrm{C}$, as previously described. ${ }^{26}$

We also analyzed the mRNA and protein expression in 24 pairs of primary lung adenocarcinomas and corresponding normal lung tissues. All experiments were performed by using a protocol approved by the Institutional Review Board of the Japanese Foundation for Cancer Research (number 2007-1058).

\section{Transient and Stable Transfections}

IGFBP-2 cDNA expression construct in pcDNA3.1/Neo (Invitrogen, Carlsbad, CA) was a generous gift from Dr. Hiroaki Kataoka (Section of Oncopathology and Regenerative Biology, Department of Pathology, University of Miyazaki, Japan). ${ }^{27}$ Cells were plated at $7 \times 10^{5}$ per well in 60-mm dishes and transfected in triplicate by using the FuGENE 6 Transfection Reagent according to the manufacturer's protocol (Roche Diagnostics, Inc., Indianapolis, IN). We established stable cell lines COR-L105, NCIH522, and HOP62 overexpressing IGFBP-2 after 4 weeks of selection in $400 \mu \mathrm{g} / \mathrm{ml}$ of neomycin.

\section{RNA Preparation and Real-Time RT-PCR}

The cells and frozen tissue were collected for RNA extraction by using an RNeasy Kit (Qiagen, Valencia, CA), and total RNA was applied for first-strand cDNA synthesis with a high capacity cDNA Reverse Transcriptase kit (Applied Biosystems, Foster City, CA). Gene-specific probes and primer were obtained from Universal ProbeLibrary (number 25, Roche Applied Science, Tokyo, Japan), and primer sequences were as follows: 5'-TTGCAGACAATGGCGATGACC-3' (IGFBP-2 forward); 5'-GGGATGTGCAGGGAGTAGAGG-3' (IGFBP-2 reverse). PCR was performed in 96-well plates by using the LightCycler 480 System (Roche Applied Science). All reactions were performed at least in triplicate. The relative amounts of all mRNAs were calculated by using the comparative threshold cycle (CT) method after normalization to human $\beta 2$ microglobulin.

\section{Cell Lysis and Immunoblotting}

To obtain total protein lysates, frozen tissue and cells were homogenized and dissolved in radioimmunoprecipitation assay buffer $(150 \mathrm{mmol} / \mathrm{L}$ of $\mathrm{NaCl}, 1.0 \%$ Nonidet P40, $0.5 \%$ sodium deoxycholate, $0.1 \%$ SDS, $50 \mathrm{mmol} / \mathrm{L}$ of Tris, $\mathrm{pH}$ 7.6) containing proteinase inhibitors and phosphatase inhibitors (Nacalai Tesque, Kyoto, Japan). The protein concentration of each lysate was determined by using a protein assay reagent kit (BioRad, Hercules, CA). The total cell lysate was applied on $4 \%$ to $12 \%$ SDSpolyacrylamide gel electrophoresis. After electrophoresis, the proteins were transferred electrophoretically from the gel to polyvinylidene difluoride membranes (Millipore, Bedford, MA). The membranes were then blocked for 1 hour in blocking buffer (5\% low-fat dried milk in Trisbuffered saline) and probed with the primary antibodies overnight. After being washed, the protein content was made visible with horseradish-peroxidase-conjugated secondary antibodies followed by enhanced chemiluminescence (Amersham, Piscataway, NJ). Signal densities were quantitatively determined by ImageJ 1.36 b software $(\mathrm{NIH}$, Bethesda, MD). The primary antibodies used were raised against IGFBP-2 (C-18, Santa Cruz Biotechnology, Santa Cruz, CA), caspase-3, phosphorylated (Tyr1135/1136) and total IGF-1R $\beta$, phosphorylated (Ser 473) and total Akt, phosphorylated (Thr 202/Tyr 204) and total Erk1/2, cleaved poly ADP-ribose polymerase (PARP; all obtained from Cell Signaling Technology, Danvers, MA), and $\beta$-actin (Sigma, St. Louis, MO). LY294002 was purchased from Sigma.

\section{Caspase Activity Assay}

Caspase activities were measured by using the Caspase-Glo 3/7 assay kit according to the manufacturer's instruction (Promega, Madison, WI). Cells $\left(5 \times 10^{3}\right.$ cells/well) were placed in a 96-well culture plate, followed by treatment with dimethyl sulfoxide (DMSO) vehicle or $200 \mathrm{nmol} / \mathrm{L}$ of camptothecin for 24 hours. One hundred microliters of Caspase-Glo 3/7 reagent was added to each well and incubated for 1 hour at room temperature. 
The culture media with the reagent served as blank, and blank control value was subtracted from each sample value. Luminescence of all samples was measured by using a Tecan Spectrafluor Plus (Wako, Osaka, Japan).

\section{Enzyme-Linked Immunosorbent Assay}

IGFBP-2 concentrations in media of cell culture were determined with IGFBP-2 Duoset enzyme-linked immunosorbent assay (ELISA) Development system ( $R$ and D Systems, Minneapolis, MN) according to the manufacturer's protocol. Briefly, capture antibody was plated in a 96-well microplate and incubated overnight at room temperature. One hundred microliters of supernatant of culture media or IGFBP-2 standard were added into plate and incubate for 2 hours at room temperature, followed by the immunoreaction with IGFBP-2 detection antibody. IGFBP-2 concentration was calculated from the standard curve. All experiments were performed in duplicate or triplicate.

\section{RNA Interference}

Small-interfering RNA (siRNA) oligonucleotides for IGFBP-2 (Santa Cruz Biotechnology) and a negative control (Invitrogen) were transfected into the cells. Transfection was performed by using Lipofectamine RNAiMAX (Invitrogen) according to the manufacturer's protocol. Briefly, $60 \mathrm{pmol}$ of siRNA and $10 \mu$ l of Lipofectamine RNAiMAX were mixed in $1 \mathrm{ml}$ of Opti-MEM medium (10 nmol/L of final siRNA concentration). After 20 minutes of incubation, the mixture was added to the suspended cells and these were plated on dishes. Cells were harvested at 24-hour intervals until 72 hours after transfection.

\section{Cell Proliferation and Apoptosis}

Cell proliferation was measured as the number of viable cells, as evaluated at $450 \mathrm{~nm}$ optical density by using Cell Count reagent SF (Nacalai Tesque). Apoptotic cells were determined by Hoechst 33342 staining, and the apoptosis rate (percent of total population) was evaluated by counting apoptotic and nonapoptotic cells in at least three randomly selected fields.

\section{Immunohistochemistry}

Tissue microarrays were constructed from 169 paraffinembedded lung adenocarcinomas. Briefly, H\&E-stained sections containing representative tumor regions were selected. Tissues were punched from cancer areas of each donor block by using tissue cylinders with a diameter of $2 \mathrm{~mm}$ and then brought into a recipient paraffin block. Three tumor cores were taken per patient.

Immunohistochemistry was performed on $5-\mu$ m thick, formalin-fixed, paraffin-embedded sections by using primary antibodies for IGFBP-2 (C-18, Santa Cruz Biotechnology) and procaspase-3 (Cell Signaling Technology). Antigen retrieval was performed for 30 minutes in citrate buffer for each antibody. The slides were developed by using the labeled streptavidin biotinylated peroxidase method
(Nichirei, Tokyo, Japan) according to the manufacturer's instructions. 3,3'-Diaminobenzidine tetrahydro-chloride was used as the chromogen, and hematoxylin was used as the counterstain. A549 xenografts in nude mice were previously established ${ }^{26}$ and were used as a positive control. The primary antibody was omitted for negative controls. All immunohistochemical staining was accomplished with a Dako Autostainer (DakoCytomation, Carpenteria, CA) under the same conditions. The staining intensity of IGFBP-2 and procaspase-3 was scored semiquantitatively: positive in less than $25 \%$ of cancer cells (weak), positive in $25 \%$ to $50 \%$ of cancer cells (moderate), and positive in more than $50 \%$ of cancer cells (strong). Representative score of each patient was defined as the highest score across three cores.

\section{Statistical Analysis}

For in vitro experiments, statistical analysis was performed by using Welch's $t$-tests. Comparisons of IGFBP-2 mRNA levels in clinical samples were made by using paired $t$-test analysis. Dose/time dependency of drugs was determined by the confidence interval $(\mathrm{Cl})$ based test of slope of the linear regression. Concentrations of drugs that suppressed cell proliferation to $50 \%$ of levels exhibited by control cells (IC50) were derived from the dose-response curve. Correlation between IGFBP-2 and caspase-3 expression in immunohistochemistry was evaluated by performing the Fisher's exact test. For all analyses, $P \leq 0.05$ was considered statistically significant. Statistical analyses were performed by using the statistical programming language of R (http://www.R-project.org; accessed February 1, 2010) and Statistika (Statsoft, Inc., Tulsa, OK).

\section{Results}

\section{IGFBP-2 Is Expressed and Secreted in Lung Adenocarcinoma Cell Lines}

At first, intracellular IGFBP-2 expression levels were examined in various lung cancer cell lines by the use of Western blot. IGFBP-2 was highly expressed in A549, $\mathrm{NCl}-\mathrm{H} 460$ cells, but expressed at very low levels in HOP62 and COR-L105 cells (Figure 1A).

The levels of secreted IGFBP-2 in media were measured by ELISA. Secreted IGFBP-2 levels correlated with intracellular protein levels obtained by Western blot (Figure 1B).

\section{IGFBP-2 Expression Is Regulated Transcriptionally and Posttranslationally}

IGFBP-2 expression is physiologically up-regulated by the energy restriction or insulin-dependent diabetes mellitus. ${ }^{28,29}$ To determine whether the supplement of nutrients can alter IGFBP-2 expression in lung cancer cells, we examined the effects of glucose or serum depletion on IGFBP-2 expression in A549 cells. Glucose depletion significantly reduced IGFBP-2 levels at both protein and mRNA levels $(P=0.0017)$, whereas serum depletion did not $(P=0.311$; Figure $2 A)$. IGFBP-2 protein and mRNA levels were dependent on glucose concentration (Figure 2B). These findings suggest that IGFBP-2 expression in 

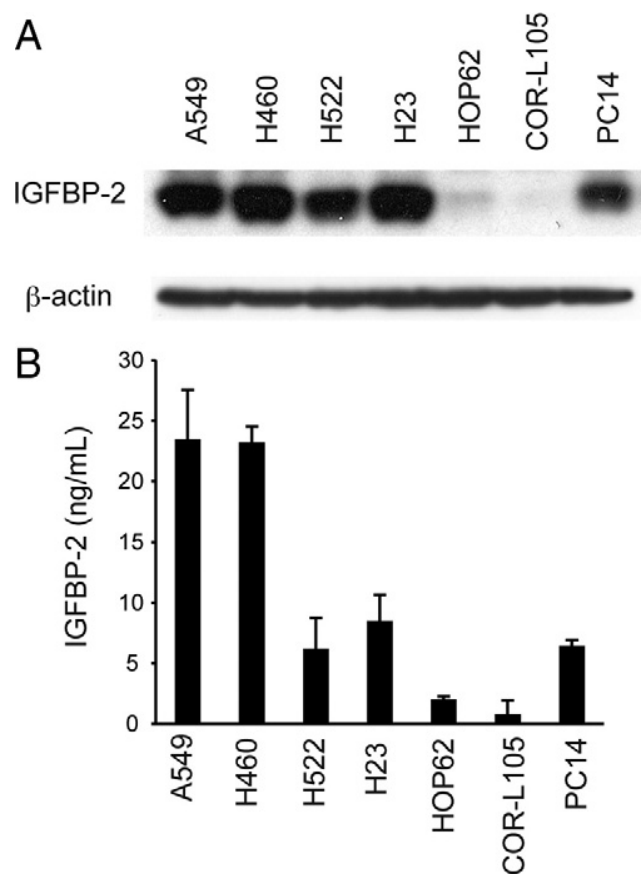

Figure 1. A: Basal levels of intracellular IGFBP-2 protein in seven lung adenocarcinoma cell lines. Cells $\left(5 \times 10^{5}\right)$ were plated in a $60-\mathrm{mm}$ dish and cultured for 48 hours. The protein extracts from each cell line were resolved by SDS-polyacrylamide gel electrophoresis and blotted with an antibody against IGFBP-2. $\beta$-actin served as internal control. A representative data from two independent experiments is shown. B: Conditioned media containing a different amount of IGFBP-2 in lung adenocarcinoma cell lines. Secreted IGFBP-2 was measured, under the same conditions as above, by ELISA. Values represent means $\pm \mathrm{SD}$

cancer cells is glucose-dependent and is regulated by a mechanism that is distinct from normal cells.

It has been reported that IGFBP-2 expression is regulated by the PI3K-PTEN (phosphatase and tensin homolog deleted on chromosome 10) pathway in prostate and glioblastoma cells. ${ }^{30}$ Thus, extracellular and intracellular IGFBP-2 levels were evaluated in lung cancer cells treated with LY294002, a PI3K inhibitor. PTEN protein was detected in all cell lines, except PC14, as described previously. ${ }^{26}$ Secretion of IGFBP-2 protein was suppressed in all cell lines by the treatment of LY294002 to varying degrees (Figure 2C). The effect of LY294002 on IGFBP-2 expression showed a significant dose dependence $(P=0.0048)$ and time course dependence (95\% Cl: 0.134 to 0.18 , control; 0.029 to 0.043, LY294002) in A549 cells (Figure 2, D and E). Intracellular IGFBP-2 levels were also decreased with LY294002 (Figure 2F). Interestingly, a fraction of IGFBP-2 protein was degraded into approximately $20 \mathrm{kDa}$ after treatment with LY294002 (Figure 2F). Conversely, IGFBP-2 mRNA was significantly increased with LY294002 ( $P<$ 0.005 ; Figure $2 \mathrm{G}$ ), suggesting the existence of a compensatory feedback mechanism.

\section{IGFBP-2 Overexpression Suppresses}

\section{Procaspase-3 Expression and Confers}

\section{Resistance for Drug-induced Apoptosis}

To address whether IGFBP-2 is involved in apoptotic event, IGFBP-2 was enforced in cells with low endoge- nous IGFBP-2 levels, and then caspase expression was examined. IGFBP-2 overexpression resulted in a remarkable increase in intracellular IGFBP-2 levels in CORL105, NCl-H522, and HOP62 cells compared with vector control (Figure 3A). Secreted IGFBP-2 levels of these cells were also increased corresponding to the levels of intracellular IGFBP-2 (Figure 3B). Intriguingly, IGFBP-2 overexpression resulted in a substantial decrease in procaspase-3 expression (Figure 3A). However, caspase-9 was not decreased (Figure 3A), suggesting IGFBP-2 specifically inhibits caspase-3 expression. Despite a higher amount of IGFBP-2 secretion into media, no significant changes were found in the IGF signaling pathway including phosphorylation statuses of IGF-1R, Akt, or Erk1/2 (Figure $3 A$ ). These findings suggest that IGFBP-2-mediated caspase-3 inhibition occurs in an IGF-independent manner.

Next, to examine whether IGFBP-2 involves in apoptotic event, we compared the sensitivity of IGFBP-2 overexpressing cells and vector control cells to an apoptosis inducer, camptothecin. IGFBP-2 overexpressing and vector control H522 cells were exposed to 20 to 1000 $\mathrm{nmol} / \mathrm{L}$ of camptothecin for 24 hours, and the cell proliferation and caspase-3 activity were analyzed. The results indicated that IGFBP-2 overexpressing H522 cells were significantly resistant to camptothecin (EV, IC50 $=686$ $\mathrm{nmol} / \mathrm{L}$; BP-2, IC50 > $1000 \mathrm{nmol} / \mathrm{L}$; Figure 3C). As expected, caspase-3 activity was significantly decreased in IGFBP-2 overexpressing cells compared with vector control cells on treatment with camptothecin $(P<0.02$; Figure 3D). Apoptosis was evaluated by Hoechst 33342 staining and PARP cleavage. Enforced IGFBP-2 significantly inhibited PARP cleavage, as determined by Western blot (Figure 3E), and reduced camptothecin-induced apoptotic cells in $\mathrm{H} 522$ cells ( $P=0.003$; Figure 3F). Similar results were obtained with the treatment of cisplatin or etoposide (data not shown).

\section{IGFBP-2 Inhibition Up-Regulates Procaspase-3 Expression and Promotes Drug-Induced Apoptosis}

To further elucidate the effects of IGFBP-2 on caspase-3, gene silencing for IGFBP-2 was performed in A549 and H522 cells. IGFBP-2 knockdown induced an increase in procaspase-3 expression until 72 hours after siRNA treatment in both cell lines (Figure 4A). No significant active form of cleaved caspase-3 was identified (data not shown). As is the results with IGFBP-2 overexpression, no substantial change was found in caspase-9. In addition, IGFBP-2 siRNA also decreased the phosphorylation status of IGF-1R. This effect might be because of a rapid decrease in both intracellular and extracellular IGFBP-2. Although IGFBP-2 knockdown resulted in morphological changes such as shrinkage in A549 cells, no substantial increase in apoptosis was identified by Hoechst 33342 staining or PARP cleavage (data not shown).

We now asked whether IGFBP-2 inhibition sensitizes cells for drug-induced apoptosis. Figure 4B shows the cell proliferation of IGFBP-2 knockdown and negative control cells with a treatment of camptothecin. IGFBP-2 
A

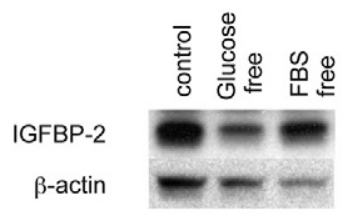

B

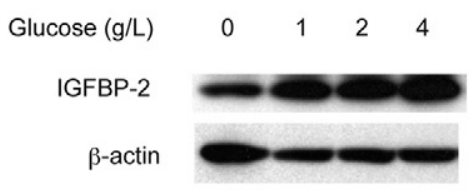

C

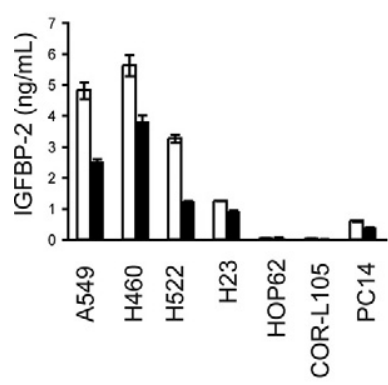

$\mathrm{F}$

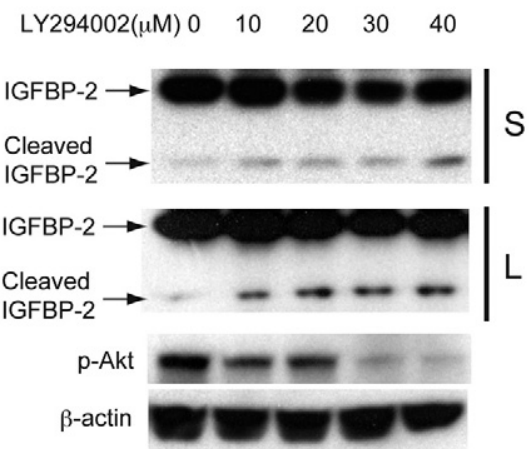

Glucose $(\mathrm{g} / \mathrm{L}) \quad 0$
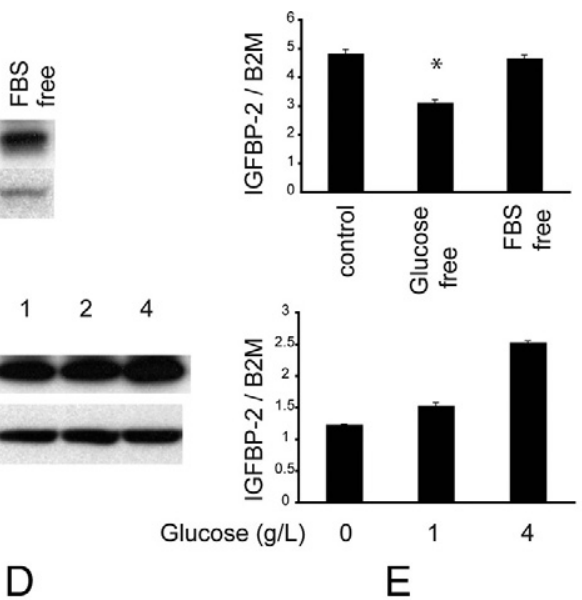

E

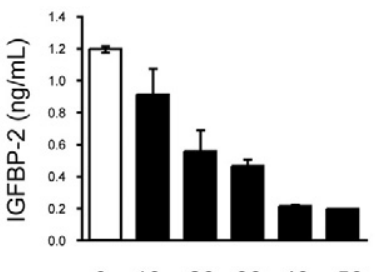

$\begin{array}{llllll}0 & 10 & 20 & 30 & 40 & 50\end{array}$

LY294002 ( $\mu \mathrm{M})$

G

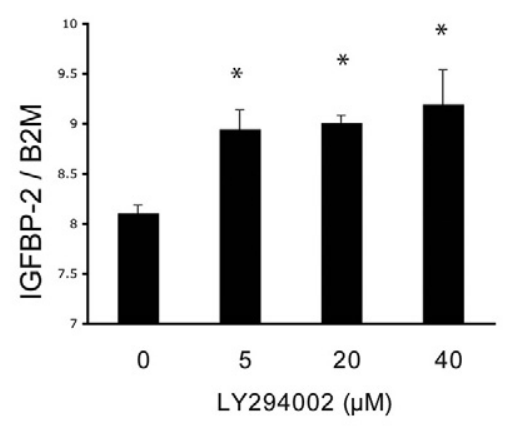

Figure 2. A: The effect of glucose and fetal bovine serum on intracellular IGFBP-2 levels. A549 cells $\left(5 \times 10^{5}\right)$ were incubated for 2 hours in fetal bovine serum (FBS) free media, followed by a 24-hour incubation in glucose free, FBS free, or regular media. The cells were then harvested and subjected to both immunoblotting and quantitative RT-PCR for IGFBP-2. IGFBP-2 mRNA was normalized to human $\beta 2$ microglobulin (B2M). Values represent means $\pm \mathrm{SD}$ Statistical analysis was performed by Welch's $t$-test. ${ }^{*} P<0.01$. B: A5 49 cells were cultured in media with the indicated concentrations of glucose for 24 hours. IGFBP-2 expression levels were measured by both immunoblotting and quantitative RT-PCR. Values represent means \pm SD. Significant slope of regression line between IGFBP-2 mRNA and glucose concentration was obtained ( $P=0.012)$. C: Effect of LY294002, a PI3K inhibitor, on extracellular IGFBP-2 levels. Seven lung adenocarcinoma cell lines were treated either with a vehicle control DMSO (white bar) or $20 \mu \mathrm{mol} / \mathrm{L}$ of LY294002 (black bar) for 24 hours. Secreted IGFBP-2 was measured by ELISA as described before. D: A549 cells were treated with the indicated concentration of LY294002 for 24 hours. A significant slope of regression line between secreted IGFBP-2 and LY294002 concentration was obtained $(P=$ $0.0048)$. E: Time course of IGFBP-2 secretion in A549 cells treated with $20 \mu \mathrm{mol} / \mathrm{L}$ of LY294002. The $95 \%$ CI based test of slope regression was significant $(P<0.05): 0.134$ to 0.18 vs. 0.029 to 0.043 , in control DMSO and LY294002, respectively. F: The effect of LY294002 on intracellular levels of IGFBP-2. A549 cells were treated with the indicated concentration of LY294002, followed by immunoblotting for IGFBP-2, phosphorylated Akt (Ser 473), and $\beta$-actin. S, short exposure; L, long exposure. G: A549 cells were treated with the indicated concentration of LY294002, and IGFBP-2 mRNA levels were evaluated by a real-time RT-PCR. Values represent means \pm SD. Statistical analysis was performed by Welch's $t$-test. ${ }^{*} P<0.01$. knockdown cells were more sensitive to campthothecin rather than vector control cells $\left(95 \% \mathrm{Cl}\right.$ : $-2.7 \times 10^{-4}$ to $-1.6 \times 10^{-4}$ vs. $-4.5 \times 10^{-4}$ to $-3.0 \times 10^{-4}$, in negative control and IGFBP-2 siRNA, respectively; Figure 4B). In caspase-3 activity assay (Figure 4C), there were no significant changes in caspase-3 activity between negative control and IGFBP-2 siRNA with DMSO treatment (white bars). When cells were treated with camptothecin, IGFBP-2 siRNA significantly increased caspase-3 activity than negative control siRNA (black bars). The sensitivity to camptothecin was significantly potentiated by IGFBP-2 inhibition $(P<0.0001)$. Apoptosis was significantly increased in cells with IGFBP-2 siRNA compared with negative control siRNA ( $P=0.0009$; Figure 4D). Cleaved PARP was more substantial in IGFBP-2 siRNA treated cells compared with vector control H522 cells (Figure 4E). As a PI3K inhibitor induced IGFBP-2 degradation (Figure 2F), we examined whether a PI3K inhibitor has an additive effect on apoptosis with camptothecin. As expected, combination therapy of LY294002 and campthothecin enhanced PARP cleavage in $\mathrm{H} 522$ cells when compared with campthothecin or LY294002 alone. IGFBP-2 levels were inversely correlated with the increase in the levels of cleaved PARP (Figure 4F, left panels). In contrast, there were no substantial effects of LY294002 on PARP cleavage in COR-L105 cells, which have low IGFBP-2 levels (Figure 4F, right panels).

These data strongly suggest that IGFBP-2 regulates apoptosis via caspase-3. Moreover, IGFBP-2 becomes a therapeutic target as well as a biomarker for the treatment of PI3K inhibitors.

\section{Tissue IGFBP-2 Is Overexpressed in Lung Adenocarcinoma}

Next, we examined tissue expression levels of IGFBP-2 in human lung adenocarcinoma and normal tissue by using 
A

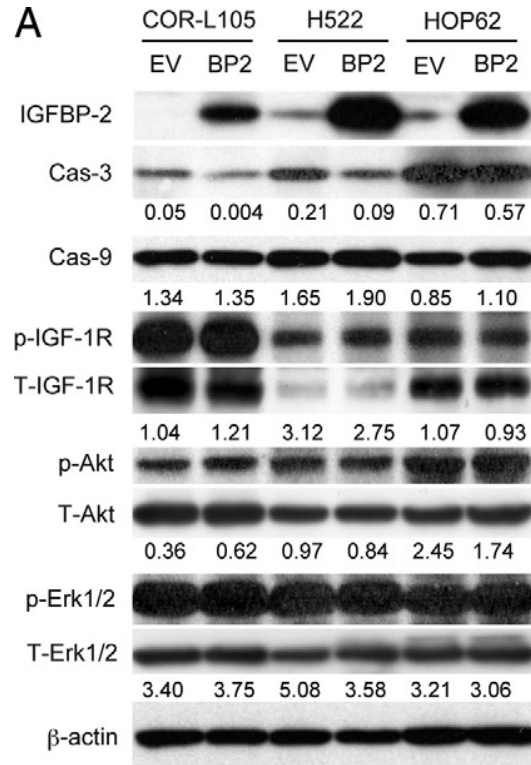

D

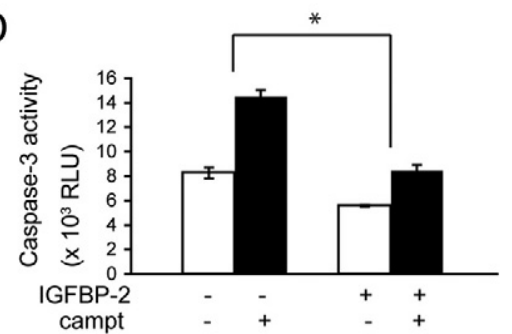

E

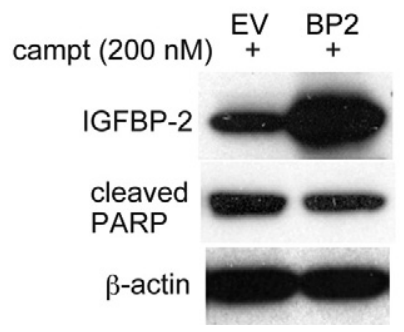

B

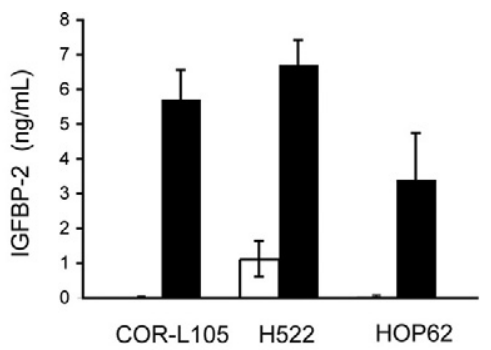

C

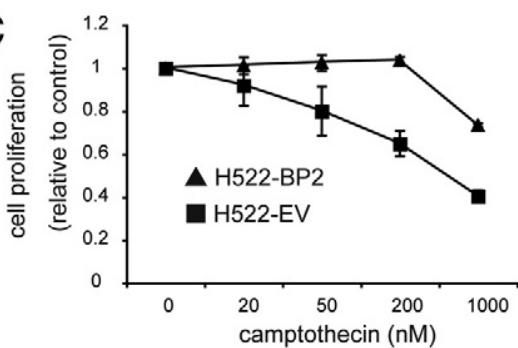

$F$

$\mathrm{EV}+\mathrm{campt}$ BP2+campt
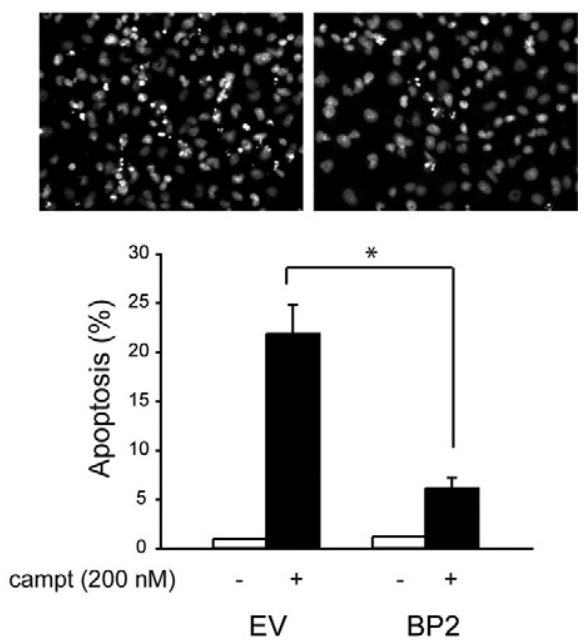

Figure 3. A: IGFBP-2 overexpression inhibits procaspase- 3 expression independent of the IGF signaling pathway. Empty vector (EV) and IGFBP-2 (BP2) were transfected in COR-L105, NCIH522, and HOP62 lung adenocarcinoma cell lines, and stably IGFBP-2 overexpressing cells were obtained. Whole cell lysates were subjected to SDS-polyacrylamide gel electrophoresis, followed by immunoblotting for IGFBP-2 procaspase-3, procaspase-9, phosphorylated and total IGF-1R, phosphorylated and total Akt, phosphorylated and total Erk1/2, and $\beta$-actin. Signal densities were quantified by ImageJ, and then procaspase- $3 / \beta$-actin, procaspase- $9 / \beta$-actin, p-IGF1R/T-IGF1R, p-Akt/T-Akt, and p-Erk1/ 2/T-Erk1/2 ratios were calculated. B: Secreted IGFBP-2 levels were measured by ELISA in three different stable vector- and IGFBP-2-transfected (white and black bars, respectively) cell lines. Data represent means \pm SD. C: IGFBP-2 overexpressing and empty vector NCI-H522 cells were plated in 96 wells and treated with indicated concentration of camptothecin for 24 hours. Cell proliferation was determined by microplate reader using cell count reagent. Data represent means \pm SD. The IC50 values were $686 \mathrm{nmol} / \mathrm{L}$ and more than $1000 \mathrm{nmol} / \mathrm{L}$ in empty vector and IGFBP-2 cells, respectively. D: Caspase-3 assay in IGFBP-2 overexpressing and empty vector NCI-H522 cells. Cells were plated in 96 wells and treated with $200 \mathrm{nmol} / \mathrm{L}$ of camptothecin for 24 hours. Caspase-3 activity was determined by a microplate reader. Data represent means $\pm S D$. Statistical analysis of comparison between empty vector and IGFBP-2 overexpressing cells was performed by Welch's $t$-test. EV (camptothecin/DMSO) versus BP2 (camptothecin/ DMSO); ${ }^{*} P<0.02$. E: Apoptosis was also evaluated by immunoblotting for PARP cleavage with whole cell lysate. F: Twenty-four hours after exposure of $200 \mathrm{nmol} / \mathrm{L}$ of camptothecin, cells were stained with Hoechst 33342. Apoptotic and nonapoptotic cells were counted by microscopy at least in three different areas, and the apoptotic rate was represented. Values represent means \pm SD. Statistical analysis was performed by Welch's $t$-test. ${ }^{*} P<0.01$. a real-time RT-PCR and Western blotting. IGFBP-2 mRNA was significantly higher in tumors than in paired normal tissue, as examined by a real-time RT-PCR $(P=0.021$; Figure 5A). A higher amount of IGFBP-2 protein was also frequently observed in tumor tissue compared with in paired normal tissue (Figure 5B).

\section{Inverse Relationship between IGFBP-2 and Caspase-3 Expression}

Finally, immunohistochemical analysis was performed on tissue microarray including 169 cases of lung adenocarcinoma. IGFBP-2 expression was mostly confined to cancer cells, whereas normal lung epithelium revealed very low or undetectable IGFBP-2 levels (Figure 6A, arrowheads). In most cases, IGFBP-2 was localized in cytoplasm of lung adenocarcinoma cells, as shown in Figure 6A. Membraneous IGFBP-2 expression was found in only 3 of 169 cases (1.8\%; Figure 6B). IGFBP-2 was expressed in early precursor lesions, and its expression levels increased gradually as the lesions progress from benign (Figure 6C, arrows) to malignant cells (Figure 6C, arrowheads). In particular, a strong IGFBP-2 expression was found in cancer cells with high nuclear grade distinct from ones with low nuclear grade even within the same gland (Figure 6D). It should be noted that the mutually exclusive expression between IGFBP-2 (Figure 6E, left panel, arrowheads and Figure 6F, left panel, upper area) and procaspase-3 (Figure 6E, right panel, arrowheads and Figure 6F, right panel, lower area) was frequently observed in lung adenocarcinomas. To summarize the immunohistochemical data, a significant inverse correlation between the groups in the numbers of patients with IGFBP-2 and procaspase-3 expression was observed in lung adenocarcinomas (Table 1).

\section{Discussion}

The IGF signaling pathway plays a pivotal role in cellular proliferation, differentiation, survival, and metabolism. 
A

A 549

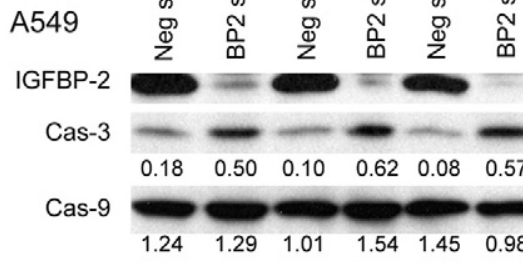

p-IGF-1R $=-\cdots$

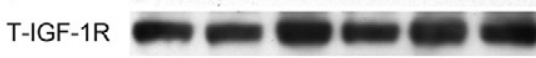

$\begin{array}{llllll}0.26 & 0.12 & 0.25 & 0.15 & 0.06 & 0.07\end{array}$

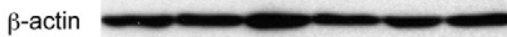

$\mathrm{H} 522$
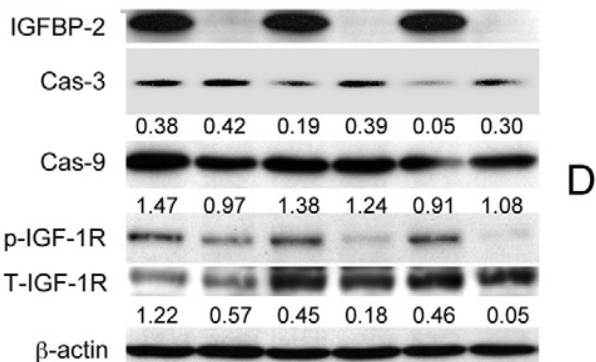

$\beta$-actin

E

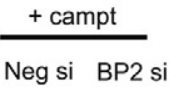

IGFBP-2

cleaved PARP

$\beta$-actin

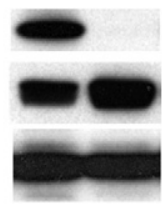

F

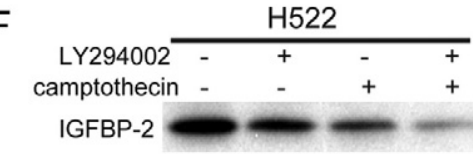

cleaved PARP

$\beta$-actin
B

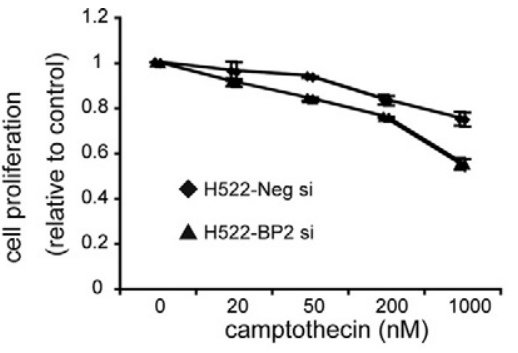

C

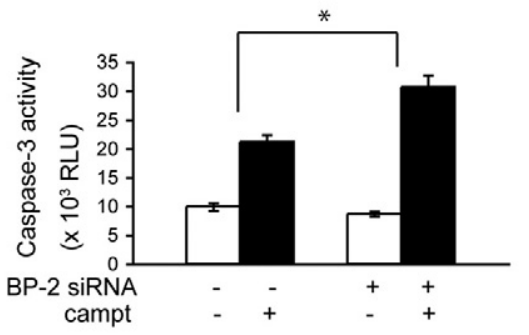

D

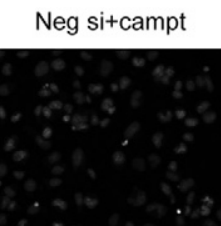

BP2 si+campt
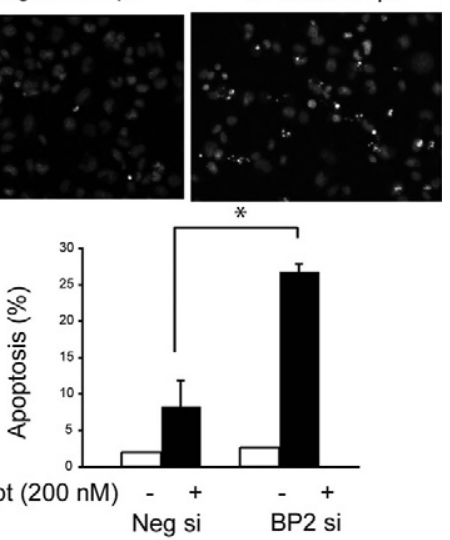

COR-L105

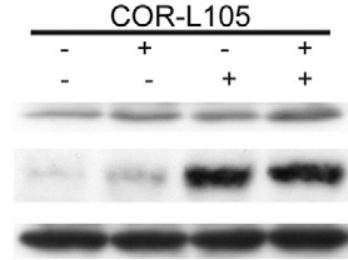

Figure 4. A: Specific IGFBP-2 inhibition resulted in the increase in procaspase-3. A549 or NCI-H522 cells were transfected with negative control or IGFBP-2 siRNA oligonucleotides, followed by immunoblot for IGFBP-2, procaspase-3, procaspase-9, phosphorylated and total IGF-1R, and $\beta$-actin at indicated times after transfection. Signal densities were quantified by ImageJ, and then procaspase$3 / \beta$-actin, Procaspase- $9 / \beta$-actin, and $\mathrm{p}-\mathrm{IGF} 1 \mathrm{R} / \mathrm{T}$ IGF1R ratios were calculated. B: NCI-H522 cells were treated with negative control or IGFBP-2 siRNA for 24 hours and then exposed to different concentrations of camptothecin for 24 hours. Cell proliferation was determined as described before. Data represent means \pm SD. A 95\% CI based test of slope regression was significant $(P<0.05)$ $-2.7 \mathrm{E}-04$ to $-1.6 \mathrm{E}-04$ in negative siRNA vs. $-4.5 \mathrm{E}-04$ to $-3.0 \mathrm{E}-04$ in IGFBP-2 siRNA. C Caspase-3 assay in NCI-H522 cells treated with negative control or IGFBP-2 siRNA. NCI-H522 cells were treated with negative control or IGFBP-2 siRNA for 48 hours in 96 wells and then treated with $200 \mathrm{nmol} / \mathrm{L}$ of camptothecin for 24 hours. Caspase-3 activity was determined by a microplate reader. Data represent means \pm SD. Statistical analysis of comparison between negative control and IGFBP-2 siRNA was performed by Welch's $t$-test. ${ }^{*} P<0.0001$. D: Twenty-four hours after exposure of $200 \mathrm{nmol} / \mathrm{L}$ of camptothecin, siRNAtreated NCI-H522 cells were stained with Hoechst 33342. The apoptotic rate was measured as described previously. Values represent means $\pm \mathrm{SD}$. Statistical analysis was performed by Welch's $t$-test. ${ }^{*} P<0.001$. E: Apoptosis was also evaluated by immunoblot for PARP cleavage in NCI-H522 cells. F: NCI-H522 and COR-L105 cells were treated with $20 \mu \mathrm{mol} / \mathrm{L}$ of LY294002 or $200 \mathrm{nmol} / \mathrm{L}$ of camptothecin or combination of LY294002 and camptothecin for 24 hours. Immunoblot was performed with IGFBP-2, cleaved PARP, and $\beta$-actin antibodies.
IGFBPs are circulating proteins and function as modulators of IGF signaling through sequestration of IGFs in serum and the extracellular fluid. Increased levels of serum IGFBP-2 are found in certain pathophysiological conditions including fasting, diabetes mellitus, growth hormone deficiency, hepatic or renal failure, and cancer. ${ }^{31}$ In cancer, IGFBP-2 exerts various biological functions by virtue of IGF-dependent or -independent mechanisms. Soluble IGFBP-2 binds to IGFs and consequently inhibits IGF signaling in various human cancers, including lung cancer. ${ }^{19,32-34}$ Membrane-associated IGFBP-2 stimulates or inhibits cell proliferation and migration through a direct binding to serum and extracellular matrix molecules, such as cell surface integrin receptors, proteoglycans, and heparin. ${ }^{2-5,35}$ Meanwhile, a number of studies demonstrate that intracellular IGFBP-2 promotes cancer cell growth in various cell types. ${ }^{9,11,36}$ Moreover, IGFBP-2 overexpression confers resistance to apoptosis induced by chemotherapy in breast cancer cells ${ }^{6}$ and by androgen ablation in prostate cancer. ${ }^{9}$ Serum IGFBP-2 can be used for prediction of chemotherapy response and prognosis in ovarian cancer ${ }^{37}$ and acute lymphoblastic leukemia. ${ }^{38}$ Notably, IGFBP-2 is a marker for antiestrogen resistance, but not for cell growth in human breast cancer cells. ${ }^{39}$ These observations invoke that intracellular IGFBP-2 mainly contributes to cancer cell survival independently of secreted IGFBP-2.

In the present study, we have shown that (1) intracellular IGFBP-2 regulates caspase-3 expression in an IGF independent manner; (2) IGFBP-2 overexpression prevents camptothecin-induced apoptosis, whereas IGFBP-2 inhibition promotes apoptosis; and (3) there is an inverse expression pattern between intracellular IGFBP-2 and caspase-3 in human lung adenocarcinomas.

We demonstrated a novel mechanism of antiapoptotic effect of IGFBP-2 via procaspase-3 inhibition in lung can- 
A
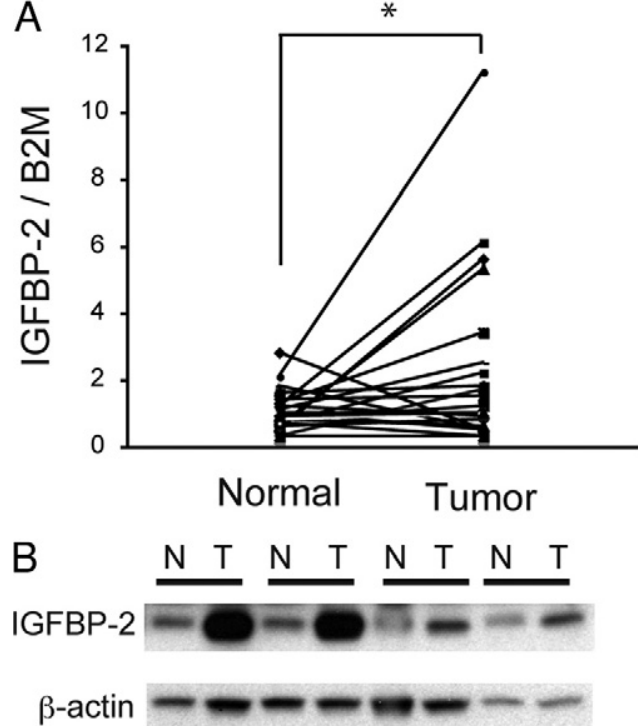

Figure 5. A: IGFBP-2 mRNA expression was measured by real-time RT-PCR in 24 pairs of human normal and corresponding tumor tissue. The mRNA levels of IGFBP-2 are presented as arbitrary units for the mRNA levels of human $\beta 2$ microglobulin (B2M). A paired $t$-test was used for statistical significance $(* P=0.021)$. B: Representative picture of Western blots. IGFBP-2 protein levels were measured with four pairs of normal $(\mathrm{N})$ and corresponding tumor $(\mathrm{T})$ tissue from lung adenocarcinoma patients.

cer. Caspases are cysteine proteases that play essential roles in mammalian apoptosis. Procaspase-3 cleavage and consequent activation is the final step of caspase cascades in response to various apoptotic stimuli. Several authors have proved that enforced procaspase-3 potentiates sensitivity to chemotherapy and promotes apoptosis. ${ }^{40-42}$ In lung cancer, decreased caspase-3 expression has been shown as a poorer prognostic factor in non-small-cell lung cancer. ${ }^{43-45}$

Our results raise the important question regarding the regulatory mechanisms involved in caspase-3 inhibition via IGFBP-2. A recent report has shown that transcriptional factor Sp1 activates the caspase-3 promoter. ${ }^{46}$ Mammalian IGFBP-2 also has the Sp1 binding regions upstream of the transcriptional start site. ${ }^{47}$ One possible explanation for the regulation of caspase-3 via IGFBP-2 is that IGFBP-2 overexpression in cancer cells inhibits Sp1 through negative feedback mechanism, and thereby inhibits caspase-3 gene and protein expression. Another possibility is PTEN. IGFBP-2 has been identified as the most significant molecular signature for loss of PTEN in brain and prostate cancer. ${ }^{30}$ It has been shown that PTEN is cleaved by caspase- 3 in a PTEN phosphorylation-regulated manner. ${ }^{48}$ IGFBP-2 overexpression may induce PTEN up-regulation and protein stabilization through feedback mechanisms, and thereby negatively regulating caspase-3 activation. Future studies will help to identify the precise regulatory mechanism of caspase-3 mediated by IGFBP-2. Recent studies demonstrate caspase-3 has apoptosis-independent physiological functions, including differentiation, maturation, proliferation, and immuno response. ${ }^{49,50}$ Thus, caspase-3 may contribute to lung cancer development and progression by multiple functions including apoptosis.
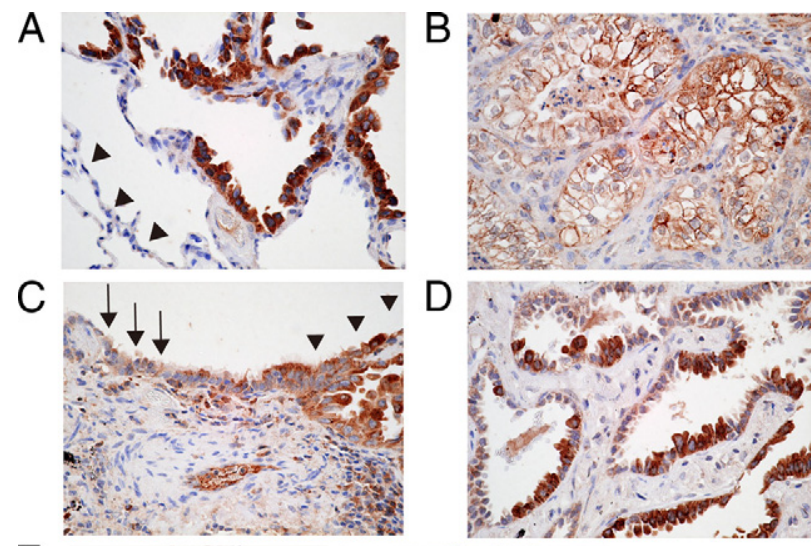

E

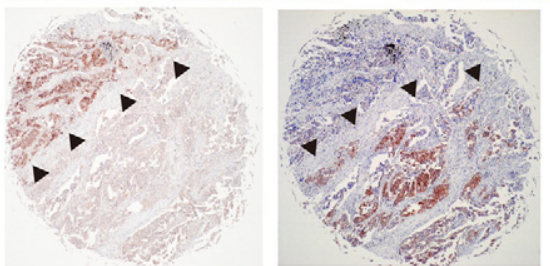

$\mathrm{F}$

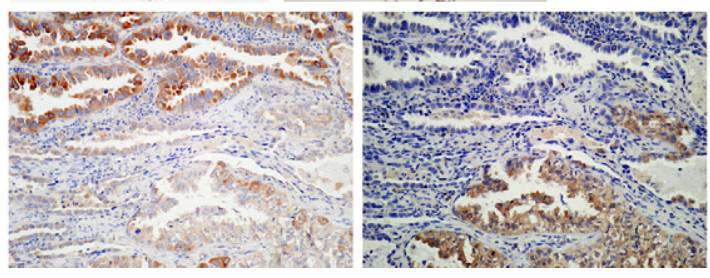

Figure 6. A: Representative pictures of immunohistochemistry for IGFBP-2 in lung adenocarcinomas. Note a strong immunoreactivity in cytoplasm of cancer cells, whereas almost negligible in normal epithelium (arrowheads). B: Typical membraneous IGFBP-2 expression. C: IGFBP-2 expression is gradually increased from benign cells (arrows) to malignant cells (arrowheads). D: Strong IGFBP-2 expression is only localized in cancer cells with high nuclear grade. E: Representative mutually exclusive expression between IGFBP-2 (left, arrowheads) and procaspase-3 (right, arrowheads) in serial sections on tissue microarray. F: Another case also demonstrates an inverse expression pattern between IGFBP-2 (left) and procaspase-3 (right) in serial sections. Original magnification: $\times 400(\mathbf{A}-\mathbf{D}$, and $\mathbf{F}) ; \times 100(\mathbf{E})$.

Because IGF signaling was not altered by the overexpression of intracellular IGFBP-2, our data suggest that intracellular and secreted IGFBP-2 are functionally independent. Interestingly, IGFBP-5 is another cancer-associated IGFBP, and it has been reported that intracellular IGFBP-5 induces growth inhibition and caspase-dependent apoptosis of breast cancer cells, whereas adding secreted-IGFBP-5 was not internalized and had no effects on growth and apoptosis. ${ }^{51}$ Further, endogenous and exogenous IGFBP-5 is suggested to exhibit opposing actions on cell survival in osteosarcoma cells. ${ }^{52}$ IGFBP-3, a most major IGFBP in serum, also induces

Table 1. Inverse Relationship between IGFBP-2 and Caspase-3 Expression in 169 Cases of Lung Adenocarcinomas

\begin{tabular}{lccc}
\hline & \multicolumn{3}{c}{ Caspase-3 } \\
\cline { 2 - 4 } IGFBP-2 & Weak & Moderate & Strong \\
\hline Weak & 48 & 20 & 10 \\
Moderate & 40 & 9 & 2 \\
Strong & 40 & 0 & 0 \\
\hline
\end{tabular}

Fisher's exact test was used for statistical significance $(P=0.0002)$ Data represent the number of patients. 
growth inhibition and apoptosis in cancer cells, but it does not require the cell surface binding and nuclear translocation of IGFBP-3 in breast and prostate cancer. ${ }^{53,54}$ These lines of evidence prompt us to propose that intracellular IGFBP-2 elicits antiapoptosis effects on cancer cells via intracrine mechanism, independent of secreted IGFBP-2. Although not yet identified in IGFBP-2, the posttranslational modification (ie, glycosylation) of secreted IGFBP-3 or -5 can be involved in the functional difference between intracellular and secreted form. ${ }^{51}$

There are a number of lines of evidence that IGFBP-3 is able to induce apoptosis and potentiate the apoptotic effects of UV or chemotherapy. ${ }^{55,56}$ The inverse relationship between IGFBP-2 and IGFBP-3 expression at tissue and serum levels in a variety of cancers, including prostate, ${ }^{31,55,57}$ ovarian, ${ }^{58}$ and testicular cancer, has been well recognized. ${ }^{59}$ We also found a relatively inverse relationship between secreted levels of IGFBP-2 and IGFBP-3 in lung adenocarcinoma cell lines (unpublished data). Remarkably, IGFBP-2 is predominantly expressed in cytoplasm and nucleus of lung epithelium when exposed to hyperoxia, whereas IGFBP-3 is localized in the extracellular compartment. ${ }^{60}$ These findings suggest that IGFBP-2 and -3 may be differentially regulated and also exert a distinct action for cell proliferation and apoptosis in different compartments.

Our immunohistochemical analysis demonstrated that most adenocarcinomas revealed a cytoplasmic IGFBP-2 expression pattern, and a significant inverse association between IGFBP-2 and procaspase-3 expression. These results support the evidence that intracellular IGFBP-2 regulates procaspase-3 expression in vitro, thereby inhibiting apoptosis. Interestingly, IGFBP-2 expression showed a marked heterogeneity within lung adenocarcinoma tissue. At cellular levels, a strong IGFBP-2 expression was found in cancer cells having high nuclear grade. This finding suggests IGFBP-2 overexpression in cancer cells is caused by adaptive mechanisms in tumor microenvironment and confers aggressive biological nature to survive under the toxic conditions.

IGFBP-2 protein is degraded by proteases such as matrix metalloprotease- 1 and -7 , calpain, as well as by basic fibroblast growth factor and an androgen blockade. ${ }^{61-64}$ We found IGFBP-2 protein was degraded by a treatment of PI3K inhibitor in A549 cells. Because a various new PI3K inhibitors have been entered clinical trials, ${ }^{65}$ IGFBP-2 would be a useful biomarker for the treatment with PI3K inhibitors in lung cancer as well as in glioma, prostate, and breast cancers. ${ }^{30,66}$ Further, our results suggested that IGFBP-2 is a therapeutic target in lung cancer, in line with the results in breast and ovarian cancers. ${ }^{6,10}$ In general, lung adenocarcinomas typically showed a resistance to multiple cancer chemotherapy. Because cytoplasmic IGFBP-2 may provide cancer cells with an antiapoptotic ability, IGFBP-2 is an attractive therapeutic target especially for chemotherapy resistant tumors. The combination of chemotherapy and the IGFBP-2 or PI3K inhibitors may also potentiate drug-sensitivity.

Lung cancer is the leading cause of cancer death worldwide. Despite the availability of some cytotoxins and molecular target therapy, the efficacy of these agents is limited.
It has thus become increasingly necessary to identify novel approaches to treat lung cancer. We propose that IGFBP-2 is not only a useful biomarker for predicting chemotherapy response, but also a novel therapeutic target in lung cancer.

\section{Acknowledgments}

We thank Ms. Tomoyo Kakita, Ms. Mayumi Ogawa, and Mr. Hironori Murayama for their excellent technical assistance, and Dr. Hiroaki Kataoka for IGFBP-2 constructs. We also thank Dr. Farid Gizatullin for helpful discussion.

\section{References}

1. Pereira JJ, Meyer T, Docherty SE, Reid HH, Marshall J, Thompson EW, Rossjohn J, Price JT: Bimolecular interaction of insulin-like growth factor (IGF) binding protein-2 with alphavbeta3 negatively modulates IGF-I-mediated migration and tumor growth. Cancer Res 2004, 64:977-984

2. Wang GK, Hu L, Fuller GN, Zhang W: An interaction between insulinlike growth factor-binding protein 2 (IGFBP2) and integrin alpha5 is essential for IGFBP2-induced cell mobility. J Biol Chem 2006 , 281:14085-14091

3. Russo VC, Bach LA, Fosang AJ, Baker NL, Werther GA: Insulin-like growth factor binding protein-2 binds to cell surface proteoglycans in the rat brain olfactory bulb. Endocrinology 1997, 138:4858-4867

4. Schutt BS, Langkamp M, Rauschnabel U, Ranke MB, Elmlinger MW: Integrin-mediated action of insulin-like growth factor binding protein-2 in tumor cells. J Mol Endocrinol 2004, 32:859-868

5. Firth SM, Baxter RC: Cellular actions of the insulin-like growth factor binding proteins. Endocr Rev 2002, 23:824-854

6. So Al, Levitt RJ, Eigl B, Fazli L, Muramaki M, Leung S, Cheang MC, Nielsen TO, Gleave M, Pollak M: Insulin-like growth factor binding protein-2 is a novel therapeutic target associated with breast cancer. Clin Cancer Res 2008, 14:6944-6954

7. Wang $H$, Wang $H$, Shen W, Huang $H$, Hu L, Ramdas L, Zhou YH, Liao WS, Fuller GN, Zhang W: Insulin-like growth factor binding protein 2 enhances glioblastoma invasion by activating invasion-enhancing genes. Cancer Res 2003, 63:4315-4321

8. Miyake H, Hara I, Yamanaka K, Muramaki M, Gleave M, Eto H: Introduction of insulin-like growth factor binding protein-2 gene into human bladder cancer cells enhances their metastatic potential. Oncol Rep 2005, 13:341-345

9. Kiyama S, Morrison K, Zellweger T, Akbari M, Cox M, Yu D, Miyake H, Gleave ME: Castration-induced increases in insulin-like growth factorbinding protein 2 promotes proliferation of androgen-independent human prostate LNCaP tumors. Cancer Res 2003, 63:3575-3584

10. Lee EJ, Mircean C, Shmulevich I, Wang H, Liu J, Niemisto A, Kavanagh $\mathrm{JJ}$, Lee JH, Zhang W: Insulin-like growth factor binding protein 2 promotes ovarian cancer cell invasion. Mol Cancer 2005, 4:7

11. Hoeflich A, Fettscher O, Lahm H, Blum WF, Kolb HJ, Engelhardt D, Wolf E, Weber MM: Overexpression of insulin-like growth factorbinding protein-2 results in increased tumorigenic potential in $\mathrm{Y}$-1 adrenocortical tumor cells. Cancer Res 2000, 60:834-838

12. Diehl D, Hessel E, Oesterle D, Renner-Muller I, Elmlinger M, Langhammer M, Gottlicher M, Wolf E, Lahm H, Hoeflich A: IGFBP-2 overexpression reduces the appearance of dysplastic aberrant crypt foci and inhibits growth of adenomas in chemically induced colorectal carcinogenesis. Int J Cancer 2009, 124:2220-2225

13. Dunlap SM, Celestino J, Wang H, Jiang R, Holland EC, Fuller GN, Zhang W: Insulin-like growth factor binding protein 2 promotes glioma development and progression. Proc Natl Acad Sci USA: 2007 , 104:11736-11741

14. Hoeflich A, Reisinger R, Lahm H, Kiess W, Blum WF, Kolb HJ, Weber $\mathrm{MM}$, Wolf $\mathrm{E}$ : Insulin-like growth factor-binding protein 2 in tumorigenesis: protector or promoter? Cancer Res 2001, 61:8601-8610

15. Fuller GN, Rhee CH, Hess KR, Caskey LS, Wang R, Bruner JM, Yung WK, Zhang W: Reactivation of insulin-like growth factor binding pro- 
tein 2 expression in glioblastoma multiforme: a revelation by parallel gene expression profiling. Cancer Res 1999, 59:4228-4232

16. Kanety H, Madjar Y, Dagan Y, Levi J, Papa MZ, Pariente C, Goldwasser $B$, Karasik A: Serum insulin-like growth factor-binding protein-2 (IGFBP-2) is increased and IGFBP-3 is decreased in patients with prostate cancer: correlation with serum prostate-specific antigen. J Clin Endocrinol Metab 1993, 77:229-233

17. Lee DY, Kim SJ, Lee YC: Serum insulin-like growth factor (IGF)-I and IGF-binding proteins in lung cancer patients. J Korean Med Sci 1999, 14:401-404

18. Yazawa $T$, Sato $H$, Shimoyamada $H$, Okudela K, Woo T, Tajiri M, Ogura T, Ogawa N, Suzuki T, Mitsui H, Ishii J, Miyata C, Sakaeda M, Goto K, Kashiwagi K, Masuda M, Takahashi T, Kitamura H: Neuroendocrine cancer-specific up-regulating mechanism of insulin-like growth factor binding protein-2 in small cell lung cancer. Am J Pathol 2009, 175:976-987

19. Sato H, Yazawa T, Suzuki T, Shimoyamada H, Okudela K, Ikeda M, Hamada K, Yamada-Okabe H, Yao M, Kubota Y, Takahashi T, Kamma $\mathrm{H}$, Kitamura $\mathrm{H}$ : Growth regulation via insulin-like growth factor binding protein-4 and -2 in association with mutant K-ras in lung epithelia. Am J Pathol 2006, 169:1550-1566

20. el Atiq F, Garrouste F, Remacle-Bonnet M, Sastre B, Pommier G: Alterations in serum levels of insulin-like growth factors and insulinlike growth-factor-binding proteins in patients with colorectal cancer. Int J Cancer 1994, 57:491-497

21. Karasik A, Menczer J, Pariente C, Kanety H: Insulin-like growth factor-I (IGF-I) and IGF-binding protein-2 are increased in cyst fluids of epithelial ovarian cancer. J Clin Endocrinol Metab 1994, 78:271-276

22. Boulle N, Logie A, Gicquel C, Perin L, Le Bouc Y: Increased levels of insulin-like growth factor II (IGF-II) and IGF-binding protein-2 are associated with malignancy in sporadic adrenocortical tumors. J Clin Endocrinol Metab 1998, 83:1713-1720

23. Busund LT, Richardsen E, Busund R, Ukkonen T, Bjornsen T, Busch C. Stalsberg H: Significant expression of IGFBP2 in breast cancer compared with benign lesions. J Clin Pathol 2005, 58:361-366

24. Mohnike KL, Kluba U, Mittler U, Aumann V, Vorwerk P, Blum WF: Serum levels of insulin-like growth factor-I, -II and insulin-like growth factor binding proteins -2 and -3 in children with acute lymphoblastic leukaemia. Eur J Pediatr 1996, 155:81-86

25. DeGraff DJ, Aguiar AA, Sikes RA: Disease evidence for IGFBP-2 as a key player in prostate cancer progression and development of osteosclerotic lesions. Am J Transl Res 2009, 1:115-130

26. Migita $T$, Narita $T$, Nomura $K$, Miyagi $E$, Inazuka $F$, Matsuura $M$, Ushijima M, Mashima T, Seimiya H, Satoh Y, Okumura S, Nakagawa K, Ishikawa Y: ATP citrate lyase: activation and therapeutic implications in non-small cell lung cancer. Cancer Res 2008, 68:8547-8554

27. Fukushima T, Tezuka T, Shimomura T, Nakano S, Kataoka H: Silencing of insulin-like growth factor-binding protein-2 in human glioblastoma cells reduces both invasiveness and expression of progressionassociated gene CD24. J Biol Chem 2007, 282:18634-18644

28. Rajaram S, Baylink DJ, Mohan S: Insulin-like growth factor-binding proteins in serum and other biological fluids: regulation and functions. Endocr Rev 1997, 18:801-831

29. Kaaks R, Lukanova A: Energy balance and cancer: the role of insulin and insulin-like growth factor-I. Proc Nutr Soc 2001, 60:91-106

30. Mehrian-Shai R, Chen CD, Shi T, Horvath S, Nelson SF, Reichardt JK, Sawyers CL: Insulin growth factor-binding protein 2 is a candidate biomarker for PTEN status and PI3K/Akt pathway activation in glioblastoma and prostate cancer. Proc Natl Acad Sci USA 2007 104:5563-5568

31. Blum WF, Horn N, Kratzsch J, Jorgensen JO, Juul A, Teale D, Mohnike K, Ranke MB: Clinical studies of IGFBP-2 by radioimmunoassay. Growth Regul 1993, 3:100-104

32. Reeve JG, Morgan J, Schwander J, Bleehen NM: Role for membrane and secreted insulin-like growth factor-binding protein-2 in the regulation of insulin-like growth factor action in lung tumors. Cancer Res 1993, 53:4680-4685

33. Grimberg A, Coleman CM, Shi Z, Burns TF, MacLachlan TK, Wang W, EI-Deiry WS: Insulin-like growth factor binding protein-2 is a novel mediator of p53 inhibition of insulin-like growth factor signaling. Cancer Biol Ther 2006, 5:1408-1414

34. Lukanova A, Toniolo P, Akhmedkhanov A, Biessy C, Haley NJ, Shore RE, Riboli E, Rinaldi S, Kaaks R: A prospective study of insulin-like growth factor-I. IGF-binding proteins-1, -2 and -3 and lung cancer risk in women. Int J Cancer 2001, 92:888-892

35. Kuang Z, Yao S, Keizer DW, Wang CC, Bach LA, Forbes BE, Wallace $\mathrm{JC}$, Norton RS: Structure, dynamics and heparin binding of the Cterminal domain of insulin-like growth factor-binding protein-2 (IGFBP-2). J Mol Biol 2006, 364:690-704

36. Moore MG, Wetterau LA, Francis MJ, Peehl DM, Cohen P: Novel stimulatory role for insulin-like growth factor binding protein-2 in prostate cancer cells. Int J Cancer 2003, 105:14-19

37. Baron-Hay S, Boyle F, Ferrier A, Scott C: Elevated serum insulin-like growth factor binding protein-2 as a prognostic marker in patients with ovarian cancer. Clin Cancer Res 2004, 10:1796-1806

38. Vorwerk P, Mohnike K, Wex H, Rohl FW, Zimmermann M, Blum WF, Mittler U: Insulin-like growth factor binding protein-2 at diagnosis of childhood acute lymphoblastic leukemia and the prediction of relapse risk. J Clin Endocrinol Metab 2005, 90:3022-3027

39. Juncker-Jensen A, Lykkesfeldt AE, Worm J, Ralfkiaer U, Espelund U, Jepsen JS: Insulin-like growth factor binding protein 2 is a marker for antiestrogen resistant human breast cancer cell lines but is not a major growth regulator. Growth Horm IGF Res 2006, 16:224-239

40. Miyoshi N, Naniwa K, Kumagai T, Uchida K, Osawa T, Nakamura Y: Alpha-tocopherol-mediated caspase-3 up-regulation enhances susceptibility to apoptotic stimuli. Biochem Biophys Res Commun 2005, 334:466-473

41. Yang XH, Sladek TL, Liu X, Butler BR, Froelich CJ, Thor AD: Reconstitution of caspase 3 sensitizes MCF-7 breast cancer cells to doxorubicinand etoposide-induced apoptosis. Cancer Res 2001, 61:348-354

42. Friedrich K, Wieder T, Von Haefen C, Radetzki S, Janicke R, SchulzeOsthoff K, Dorken B, Daniel PT: Overexpression of caspase-3 restores sensitivity for drug-induced apoptosis in breast cancer cell lines with acquired drug resistance. Oncogene 2001, 20:2749-2760

43. Saad AG, Yeap BY, Thunnissen FB, Pinkus GS, Pinkus JL, Loda M, Sugarbaker DJ, Johnson BE, Chirieac LR: Immunohistochemical markers associated with brain metastases in patients with non-smallcell lung carcinoma. Cancer 2008, 113:2129-2138

44. Yoo J, Jung JH, Lee MA, Seo KJ, Shim BY, Kim SH, Cho DG, Ahn MI, Kim CH, Cho KD, Kang SJ, Kim HK: Immunohistochemical analysis of non-small cell lung cancer: correlation with clinical parameters and prognosis. J Korean Med Sci 2007, 22:318-325

45. Koomagi R, Volm M: Relationship between the expression of caspase-3 and the clinical outcome of patients with non-small cell lung cancer. Anticancer Res 2000, 20:493-496

46. Sudhakar C, Jain N, Swarup G: Sp1-like sequences mediate human caspase-3 promoter activation by p73 and cisplatin. Febs J 2008, 275:2200-2213

47. Kutoh E, Margot JB, Schwander J: Identification and characterization of the putative retinoblastoma control element of the rat insulin-like growth factor binding protein-2 gene. Cancer Lett 1999, 136:187-194

48. Torres J, Rodriguez J, Myers MP, Valiente M, Graves JD, Tonks NK, Pulido R: Phosphorylation-regulated cleavage of the tumor suppressor PTEN by caspase-3: implications for the control of protein stability and PTEN-protein interactions. J Biol Chem 2003, 278:30652-30660

49. Kuranaga E, Miura M: Nonapoptotic functions of caspases: caspases as regulatory molecules for immunity and cell-fate determination. Trends Cell Biol 2007, 17:135-144

50. Nhan TQ, Liles WC, Schwartz SM: Physiological functions of caspases beyond cell death. Am J Pathol 2006, 169:729-737

51. Butt AJ, Dickson KA, McDougall F, Baxter RC: Insulin-like growth factor-binding protein-5 inhibits the growth of human breast cancer cells in vitro and in vivo. J Biol Chem 2003, 278:29676-29685

52. Yin $P, X u Q$, Duan C: Paradoxical actions of endogenous and exogenous insulin-like growth factor-binding protein-5 revealed by RNA interference analysis. J Biol Chem 2004, 279:32660-32666

53. Bhattacharyya N, Pechhold K, Shahjee H, Zappala G, Elbi C, Raaka B, Wiench M, Hong J, Rechler MM: Nonsecreted insulin-like growth factor binding protein-3 (IGFBP-3) can induce apoptosis in human prostate cancer cells by IGF-independent mechanisms without being concentrated in the nucleus. J Biol Chem 2006, 281:24588-24601

54. Butt AJ, Fraley KA, Firth SM, Baxter RC: IGF-binding protein-3-induced growth inhibition and apoptosis do not require cell surface binding and nuclear translocation in human breast cancer cells. Endocrinology 2002, 143:2693-2699

55. Nickerson T, Huynh H, Pollak M: Insulin-like growth factor binding 
protein-3 induces apoptosis in MCF7 breast cancer cells. Biochem Biophys Res Commun 1997, 237:690-693

56. Rajah R, Valentinis B, Cohen P: Insulin-like growth factor (IGF)-binding protein-3 induces apoptosis and mediates the effects of transforming growth factor-beta1 on programmed cell death through a p53- and IGF-independent mechanism. J Biol Chem 1997, 272:12181-12188

57. Tennant MK, Thrasher JB, Twomey PA, Birnbaum RS, Plymate SR: Insulin-like growth factor-binding protein-2 and -3 expression in benign human prostate epithelium, prostate intraepithelial neoplasia, and adenocarcinoma of the prostate. J Clin Endocrinol Metab 1996, 81:411-420

58. Flyvbjerg A, Mogensen O, Mogensen B, Nielsen OS: Elevated serum insulin-like growth factor-binding protein 2 (IGFBP-2) and decreased IGFBP-3 in epithelial ovarian cancer: correlation with cancer antigen 125 and tumor-associated trypsin inhibitor. J Clin Endocrinol Metab 1997, 82:2308-2313

59. Fottner C, Sattarova S, Hoffmann K, Spottl G, Weber MM: Elevated serum levels of IGF-binding protein 2 in patients with non-seminomatous germ cell cancer: correlation with tumor markers alpha-fetoprotein and human chorionic gonadotropin. Eur J Endocrinol 2008, 159:317-327

60. Besnard V, Corroyer S, Trugnan G, Chadelat K, Nabeyrat E, Cazals V, Clement A: Distinct patterns of insulin-like growth factor binding protein (IGFBP)-2 and IGFBP-3 expression in oxidant exposed lung epithelial cells. Biochim Biophys Acta 2001, 1538:47-58

61. Berg U, Bang P, Carlsson-Skwirut C: Calpain proteolysis of insulinlike growth factor binding protein (IGFBP) -2 and -3 , but not of IGFBP-1. Biol Chem 2007, 388:859-863

62. Nakamura M, Miyamoto S, Maeda H, Ishii G, Hasebe T, Chiba T, Asaka M, Ochiai A: Matrix metalloproteinase-7 degrades all insulin-like growth factor binding proteins and facilitates insulin-like growth factor bioavailability. Biochem Biophys Res Commun 2005, 333:1011-1016

63. DeGraff DJ, Malik M, Chen Q, Miyako K, Rejto L, Aguiar AA, Bancroft DR, Cohen P, Sikes RA: Hormonal regulation of IGFBP-2 proteolysis is attenuated with progression to androgen insensitivity in the LNCaP progression model. J Cell Physiol 2007, 213:261-268

64. Russo VC, Rekaris G, Baker NL, Bach LA, Werther GA: Basic fibroblast growth factor induces proteolysis of secreted and cell membrane-associated insulin-like growth factor binding protein-2 in human neuroblastoma cells. Endocrinology 1999, 140:3082-3090

65. Yap TA, Garrett MD, Walton MI, Raynaud F, de Bono JS, Workman P: Targeting the PI3K-AKT-mTOR pathway: progress, pitfalls, and promises. Curr Opin Pharmacol 2008, 8:393-412

66. Martin JL, Baxter RC: Expression of insulin-like growth factor binding protein-2 by MCF-7 breast cancer cells is regulated through the phosphatidylinositol 3-kinase/AKT/mammalian target of rapamycin pathway. Endocrinology 2007, 148:2532-2541 